\title{
Blockade of interaction of $\alpha 9$ integrin with its ligands hinders the formation of granulation in cutaneous wound healing
}

\author{
Yosuke Nakayama ${ }^{1}$, Shigeyuki Kon ${ }^{1}$, Daisuke Kurotaki ${ }^{1}$, Junko Morimoto ${ }^{1}$, Yutaka Matsui ${ }^{2}$ and Toshimitsu Uede ${ }^{1}$
}

The wound healing is a complex process consisting of inflammatory reaction, proliferation of mesenchymal cells, and formation and contraction of granulation tissue. The integrin receptors have crucial roles in this process. Recently, $\alpha 9$ integrin has also been detected on keratinocytes within wound sites. However, its functional significance at various wound healing processes was not fully elucidated. To address the role of $\alpha 9$ integrin in wound healing process, we made a full-thickness skin excisional wound and treated mice with anti- $\alpha 9$ integrin antibody. It has been shown that wound healing process was divided into three distinct phases: first, the re-epithelialization phase, second, the phase of granulation tissue formation, and finally the phase of contraction of granulation tissue. We found that contraction of granulation tissue was not impaired by blocking the interaction of $\alpha 9$ integrin with its ligands, indicating that $\alpha 9$ integrin is not involved in myofibroblast differentiation. It is noteworthy that the formation of granulation tissue, as characterized by dense vimentin and CD31-positive area, was impaired. The hindrance of granulation tissue formation is because of the inhibition of adhesion and migration of $\alpha 9$ integrin-positive dermal fibroblasts. In conclusion, $\alpha 9$ integrin is involved in the formation of granulation tissue through regulating migration and adhesion of dermal fibroblasts in the full-thickness skin excisional wound model.

Laboratory Investigation (2010) 90, 881-894; doi:10.1038/labinvest.2010.69; published online 22 March 2010

KEYWORDS: integrin; fibroblast; wound healing; osteopontin; tenascin-C

After skin injury, a dynamic wound healing process takes place. Wound healing process consists of an initial inflammatory response followed by re-epithelialization of wound area, formation of granulation tissue, accompanying neovascularization, and wound contraction. ${ }^{1,2}$ This wound healing process is tightly coordinated by the interaction of cells with their surrounding extracellular matrix (ECM) proteins and growth factors. ${ }^{3-5}$ The ECM, initially thought to exert an effect simply as a scaffold for cell adhesion, however, is now proved to be a dynamic structure, continually remodeling in response to various stimuli. The alterations in the composition of ECM then provide signals into adjacent cells through cell surface receptors. Thus, interaction of ECM with cells through cell surface receptors such as integrins regulates cell shape, proliferation, intracellular signaling, and differentiation that are critical for maintaining normal tissue function and wound healing process. ${ }^{3}$

Indeed, it has been reported that various integrins have a critical role during the process of wound healing. For example, $\alpha \mathrm{v} \beta 3$ integrin is important for angiogenesis, ${ }^{6,7}$ and many of the integrins, such as $\alpha 3 \beta 1, \alpha 5 \beta 1$, and $\alpha 6 \beta 4$, are shown to be involved in migration of keratinocytes into wound site. ${ }^{8,9}$ In addition, it has become clear that among numerous ECM proteins, there is a group of secreted ECM proteins that are important during development, but expression of these ECMs in the adult is typically restricted to wound repair and remodeling tissue. These proteins are designated as 'matricellular proteins', including thrombospondins, connective tissue growth factors, osteopontin $(\mathrm{OPN})$, and tenascin-C (TN-C). Matricellular proteins interact

\footnotetext{
${ }^{1}$ Division of Molecular Immunology, Institute for Genetic Medicine, Hokkaido University, Kita-ku, Sapporo, Japan and ${ }^{2}$ Department of Matrix Medicine, Institute for Genetic Medicine, Hokkaido University, Kita-ku, Sapporo, Japan

Correspondence: Dr T Uede, PhD, Division of Molecular Immunology, Institute for Genetic Medicine, Hokkaido University, Kita-15, Nishi-7, Kita-ku, Sapporo 060-0815, Japan.

E-mail: toshi@igm.hokudai.ac.jp

Received 14 January 2010; revised 15 January 2010; accepted 22 January 2010
} 
with integrin or modulate the activity of growth factors, and the structural components of classical ECM such as collagen. ${ }^{10}$ Many studies have focused on the role of matricellular proteins during wound healing and these studies have been conducted using matricellular protein gene-null mice. ${ }^{11}$ In thrombospondin-2-null mice, full-thickness excisional wounds healed at an accelerated rate and resolved with minimal scarring when compared with those in wild-type mice. ${ }^{12}$ On the other hand, absence of a single gene such as OPN or TN-C did not show any alteration in the rate of healing except minor histological abnormalities, suggesting that these genes have redundancies. ${ }^{13,14}$ Indeed, absence of two genes of matricellular proteins resulted in significant phenotypic alterations in wound healing. ${ }^{15,16}$ In this regard, it should be noted that OPN and TN-C share $\alpha 9 \beta 1$ integrin as a common receptor. ${ }^{17,18}$ It has also been reported that EDA/EIIIA segment of fibronectin is expressed during the granulation tissue phase of wound healing and that it is also a ligand for $\alpha 9 \beta 1$ integrin. ${ }^{19-22}$ Thus, it is interesting to examine whether $\alpha 9 \beta 1$ integrin has a pivotal role during the wound healing process. However, because of the early postnatal mortality of $\alpha 9$-deficient mice, ${ }^{23}$ a role of $\alpha 9$ integrin during the healing process of full-thickness skin wounds in mice still remains unclear. To address whether and how $\alpha 9 \beta 1$ integrin is involved in the wound healing process, we took advantage of using inhibitory anti- $\alpha 9 \beta 1$ integrin antibody (clone: $55 \mathrm{~A} 2 \mathrm{C}$ ) in full-thickness skin excisional wound model.

\section{MATERIALS AND METHODS Animals}

C57BL/6 mice were purchased from Japan SLC (Hamamatsu, Japan). All mice were housed in a specific pathogen-free barrier facility and screened regularly for pathogens. All studies and procedures were approved by the committee on animal experimentation of the Institute for Genetic Medicine, Hokkaido University.

\section{Anti-Murine $\alpha \mathbf{9}$ Integrin Antibody}

Hamster monoclonal antibodies against murine $\alpha 9$ integrin were developed. To block the function of $\alpha 9$ integrin, we used anti- $\alpha 9$ integrin antibody (clone: 55A2C) that has an inhibitory effect on the interaction between $\alpha 9$ integrin and its ligands including OPN and TN-C. ${ }^{24}$ To examine the expression of $\alpha 9$ integrin by flow cytometry analysis, we used anti- $\alpha 9$ integrin antibody (clone: 18R18D) that does not have such an inhibitory effect. ${ }^{24}$ As a control, normal hamster immunoglobulin $\mathrm{G}$ (NHG) was used.

\section{Wounding}

After shaving the dorsal hair and cleaning the exposed skin with $70 \%$ ethanol, full-thickness skin (including the panniculus carnosus) excisional wound was made on the back of 8 week-old female C57BL/6 mice using 5-mm biopsy punch (Nipro, Osaka, Japan). The edges of the wound were traced onto a transparency, and the areas of open wounds were calculated using ImageJ software (Version $1.38 \times, \mathrm{NIH}$, Bethesda, MD, USA) as previously reported. ${ }^{25}$ Wounds were left uncovered and harvested using 5 -mm biopsy punch at 1 , $3,5,7,10$, and 14 days after wounding.

\section{Tissue Harvesting}

For histological analysis, wounds including small margin of surrounding skin were removed and bisected. Tissue was embedded in Tissue-Tek OCT compound (Sakura Finetek Japan, Tokyo, Japan) and stored at $-80^{\circ} \mathrm{C}$. The samples were sectioned at $5 \mu \mathrm{m}$ thickness with a cryostat, air-dried for $2 \mathrm{~h}$, and then fixed for $7 \mathrm{~min}$ in acetone at $-20{ }^{\circ} \mathrm{C}$. Tissue sections were stored at $-80{ }^{\circ} \mathrm{C}$ until use.

\section{Culture of Primary Fibroblasts}

Adult mouse subcutaneous fibroblasts were prepared from 8-week-old C57BL/6 mice. In brief, a full thickness of the back skin was cut out by scissors, and then cut into small pieces. The skin was implanted into plastic tissue culture dishes containing TIL medium (IBL, Gunma, Japan) with $10 \%$ fetal bovine serum (PAA Laboratories $\mathrm{GmbH}$, Pasching, Austria), $2 \mathrm{mM}$ glutamine, $100 \mathrm{units} / \mathrm{ml}$ penicillin, and $100 \mu \mathrm{g} / \mathrm{ml}$ streptomycin (Sigma). After 2 weeks, proliferative cells were harvested and subcultured. The fibroblasts were used between passages 3 and 5 for experiments.

\section{Immunohistochemistry and Immunofluorescence}

Tissue sections were stained with hematoxylin and eosin or used for immunohistochemistry. For immunohistochemistry, sections were blocked in 10\% normal goat serum (Jackson ImmunoResearch Laboratories, West Grove, PA, USA) in phosphate-buffered saline (PBS) for $30 \mathrm{~min}$ at room temperature. To further block endogenous peroxidase, sections were treated with $0.3 \% \mathrm{H}_{2} \mathrm{O}_{2}$ in PBS for $5 \mathrm{~min}$. Sections were incubated with the primary antibody overnight at $4{ }^{\circ} \mathrm{C}$. Rat monoclonal antibodies specific for mouse CD31 (BMA Biomedicals, Augst, Switzerland), F4/80 (BioLegend, San Diego, CA, USA), mouse monoclonal antibody specific for vimentin (Sigma-Aldrich, St Louis, MO, USA), and rat monoclonal antibody specific for Ki-67 (Dako Japan, Tokyo, Japan) were diluted 1:400, 1:200, 1:200, and 1:200 in 10\% goat serum in PBS, respectively. The primary monoclonal antibody specific for $\alpha$-smooth muscle actin ( $\alpha$-SMA) (clone 1A4, Sigma) were biotinylated by Biotin Labeling Kit- $\mathrm{NH}_{2}$ (Dojindo Molecular Technologies, Rockville, MD, USA) and diluted at $5 \mu \mathrm{g} / \mathrm{ml}$. Sections were then incubated sequentially for $30 \mathrm{~min}$ at room temperature with a biotinylated secondary antibody, and then with Vectastain $\mathrm{ABC}$ kit (Vector Laboratories, Burlingame, CA, USA) for $30 \mathrm{~min}$ at room temperature. After incubation, sections were washed three times with PBS, developed with DAKO EnVision + kit/ HRP (DAB; Dako Japan), and then counterstained with hematoxylin. 
For immunofluorescence, $3.0 \times 10^{4}$ dermal fibroblasts were plated on $0.5 \%$ gelatin pre-coated Lab-Tek II chamber slide (Thermo Scientific, Rockford, IL, USA). After overnight incubation, samples were fixed in $2 \%$ paraformaldehyde followed by permeabilization with $0.1 \%$ Triton X-100. Samples were then incubated for $30 \mathrm{~min}$ at room temperature with either anti-vimentin (diluted 1:200) or FITC-conjugated anti- $\alpha$-SMA (diluted 1:250; clone 1A4, Sigma) in TIL medium containing $10 \%$ fetal bovine serum. Samples were incubated for $30 \mathrm{~min}$ with FITC-conjugated anti-mouse IgM (diluted 1:100; Jackson ImmunoResearch Laboratories) and/ or rhodamine-phalloidin (diluted 1:200; Invitrogen/Molecular Probes, Carlsbad, CA, USA) in TIL medium containing $10 \%$ fetal bovine serum, and then counterstained and embedded in VECTASHIELD Mounting Medium with DAPI (Vector Laboratories). For negative control, purified mouse IgM (diluted $5 \mu \mathrm{g} / \mathrm{ml}$; Invitrogen) was used as a substitute for primary antibody.

\section{Image Analysis and Morphometry}

The degree of wound healing was evaluated using sections of wounded skin stained with hematoxylin and eosin. The extent of wound contraction was determined by the wound width as described previously, ${ }^{26}$ and was defined as the distance between the cut ends of the connective tissues (as indicated by arrow in Figure 7a). Granulation tissue was defined as the area that consisted of collection of vimentinpositive fibroblasts, CD31-positive newly formed blood vessels, and F4/80-positive macrophages (as shown in Figure 4ac), as described previously. ${ }^{27}$ Using free-hand tool of Photoshop (Version 5.5, Adobe Systems, Tokyo, Japan), the areas of granulation tissue were gated and measured using ImageJ software.

\section{RNA Isolation and Real-Time Reverse Transcriptase (RT)- PCR}

Total RNA was extracted from homogenized wound tissues or isolated fibroblasts using TRIzol (Invitrogen). First-strand cDNA was generated with the Transcriptor First-Strand cDNA Synthesis Kit (Roche Diagnostics GmbH, Mannheim, Germany). Real-time PCR was carried out with the LightCycler FastStart DNA Master SYBR Green I Kit (Roche). Primers for $\alpha 9$ integrin, $\alpha 4$ integrin, OPN, TN-C, and glyceraldehyde-3-phosphate dehydrogenase (GAPDH) were as follows: $\alpha 9$ integrin, $5^{\prime}$-AAAGGCTGCAGCTGTCCCACATG GACGAAG- $3^{\prime}$ and $5^{\prime}$-TTTAGAGAGATATTCTTCACAGCCC CCAAA- $3^{\prime} ; \alpha 4$ integrin, $5^{\prime}$-TGGAAGCTACTTAGGCTACT- $3^{\prime}$ and $5^{\prime}$-TCCCACGACTTCGGTAGTAGTAT- $3^{\prime}$; OPN, $5^{\prime}$-ACG ACCATGAGATTGGCAGTG- $3^{\prime}$ and $5^{\prime}$-TTAGTTGACCTCA GAAGATGA-3'; TN-C, 5' -TGTGTGCTTCGAAGGCTATG-3' and $5^{\prime}$-GCAGACACACTCGTTCTCCA-3'; and GAPDH, $5^{\prime}$ ACCACAGTCCATGCCATCAC- $3^{\prime}$ and $5^{\prime}$-TCCACCACCCT GTTGCTGTA- $3^{\prime}$. Expression of real-time PCR products was normalized to GAPDH.

\section{Western Blotting}

Snap-frozen wounds were homogenized in PBS with Protease Inhibitor Cocktail Tablets (Complete Mini, Roche). Dermal fibroblasts, NIH3T3 cells, and murine $\alpha 9$ integrin transfected-NIH3T3 cells $^{24}$ were lysed in $20 \mathrm{mM}$ Tris- $\mathrm{HCl}(\mathrm{pH}$ 7.5), $150 \mathrm{mM} \mathrm{NaCl}, 1 \mathrm{mM}$ EDTA, $1 \%$ Triton X-100, $2.5 \mathrm{mM}$ sodium pyrophosphate, $1 \mathrm{mM} \beta$-glycerophosphate, and $1 \mathrm{mM} \mathrm{Na} \mathrm{VO}_{4}$ containing protease inhibitor (Roche). The lysates were centrifuged at 15000 r.p.m. for $30 \mathrm{~min}$ to remove cell debris and then heated at $100{ }^{\circ} \mathrm{C}$ for $5 \mathrm{~min}$. Concentration of protein was determined using BCA Protein Assay Kit (Thermo Scientific). A total of $20 \mu \mathrm{g}$ of protein lysates was separated by SDS-PAGE using $10-12 \%$ gel. Proteins were transferred onto nitrocellulose membranes. Membranes were subsequently blocked in $5 \%$ nonfat milk in $20 \mathrm{mM}$ Tris- $\mathrm{HCl} /$ $136.9 \mathrm{mM} \mathrm{NaCl} / 0.1 \%$ Tween-20, followed by incubation with primary antibodies: against $\alpha$-SMA (clone 1A4; Sigma), GAPDH (clone 6C5; EMD Chemicals, Darmstadt, Germany), or $\alpha 9$ integrin (R\&D Systems, Minneapolis, MN, USA). After incubation with horseradish peroxide-conjugated secondary antibodies, membranes were developed using an enhanced chemiluminescence detection system (GE Healthcare UK, Buckinghamshire, UK).

\section{Flow Cytometry}

Fibroblasts were trypsinized, washed with PBS, blocked with rat anti-mouse CD16/CD32 (clone: 2.4G2, $5 \mu \mathrm{g} / \mathrm{ml} ; \mathrm{BD}$ Biosciences, San Diego, CA, USA) in FACS buffer $(0.5 \%$ bovine serum albumin (BSA) and $0.05 \% \mathrm{NaN}_{3}$ in PBS) on ice for $30 \mathrm{~min}$, incubated with $5 \mu \mathrm{g} / \mathrm{ml}$ biotinylated-hamster anti-mouse $\alpha 9$ integrin (clone: 18R18D) with $500 \mu \mathrm{g} / \mathrm{ml}$ control NHG or $500 \mu \mathrm{g} / \mathrm{ml}$ non-labeled 18R18D for $30 \mathrm{~min}$ on ice and then with $0.5 \mu \mathrm{g} / \mathrm{ml}$ streptavidin-APC in FACS buffer on ice for $20 \mathrm{~min}$. Labeled cells were suspended in PBS with $10 \mu \mathrm{g} / \mathrm{ml}$ 7-Aminoactinomycin D (Sigma) for detecting dead cells, and fluorescence was determined with a flow cytometer (FACSort, BD Biosciences).

\section{Production of Mutated Forms of TN-C}

The specific binding domain for $\alpha 9$ integrin within human TN-C exists within a third fibronectin type III repeat domain of human TN-C $\left(\mathrm{R}^{797}-\mathrm{P}^{896}\right)$ and this domain also contains a binding site for RGD-recognizing integrins. ${ }^{28}$ To study the $\alpha 9$ integrin-specific interaction of TN-C with fibroblasts, $\mathrm{R}^{797}$. $\mathrm{P}^{896}$ in which RGD was mutated to RAA (TN-C(RAA) $)^{29,30}$ was generated, thus eliminating the interaction of this mutated protein with RGD-recognizing integrins and was cloned into pGEX6p-1 from cDNA derived from HT-1080 cells using a pair of primers: TN-C-5', $5^{\prime}$-GTTGGATCCAGGGTG ACCACCACACGCTTG- $3^{\prime}$ and TN-C (RAA)- $3^{\prime}, 5^{\prime}$-TCTCTC GAGTTAGGGAGCATCGAGGCCTGTTGTGAAGGTCTCTT TGGCTGGGTTGCTTGACATGGCAGCTCT-3' . pGEX plasmid was transformed to JM109 competent cells. The glutathione $S$-transferase fusion protein was purified with glutathione sepharose $4 \mathrm{~B}$ beads, and was cut off from 
glutathione $S$-transferase with PreScission protease (GE Healthcare). Purity and concentration of product were confirmed by SDS-PAGE followed by Coomassie Blue staining and BCA Protein Assay Kit (Thermo Scientific), respectively.

\section{Cell Adhesion Assay}

A 96-well plate was coated with BSA $(2.5 \mu \mathrm{g} / \mathrm{ml})$ or TN-C (RAA) $(2.5 \mu \mathrm{g} / \mathrm{ml})$ in PBS for $1 \mathrm{~h}$ at $37^{\circ} \mathrm{C}$. Wells were blocked with $0.5 \%$ BSA in PBS for $1 \mathrm{~h}$ at room temperature and then washed with PBS. A total of 20000 cells were added to each well in $200 \mu \mathrm{l}$ of serum-free TIL medium containing $0.25 \%$ BSA in the presence or absence of NHG or 55A2C $(10 \mu \mathrm{g} /$ $\mathrm{ml}$ ). Plates were incubated at $37^{\circ} \mathrm{C}$. After $1 \mathrm{~h}$, the cells were washed with PBS, fixed, and stained with crystal violet. All wells were rinsed three times with water, and adherent cells were then lysed with $20 \%$ acetic acid. The resulting supernatants from each well were analyzed by an immunoreader (Thermo Scientific), and the absorbance at $590 \mathrm{~nm}$ was measured to determine the relative number of cells adhered to wells.

\section{Evaluation of Cell Migration by Haptotaxis Assay}

To evaluate the cell migration toward an immobilized TN-C (RAA), haptotaxis assay was performed. ${ }^{31}$ Millicell Culture Plate Insert (pore size $8 \mu \mathrm{m}$; Millipore, Tokyo, Japan) were used. The undersurface of the insert was coated with BSA $(10 \mu \mathrm{g} / \mathrm{ml})$ or TN-C(RAA) $(10 \mu \mathrm{g} / \mathrm{ml})$ in PBS for $1 \mathrm{~h}$ at $37^{\circ} \mathrm{C}$ and blocked with $0.5 \%$ BSA in PBS for $1 \mathrm{~h}$ at room temperature. Primary cultured fibroblasts were harvested and suspended in serum-free TIL medium. Cells were then pretreated by NHG or $55 \mathrm{~A} 2 \mathrm{C}(20 \mu \mathrm{g} / \mathrm{ml})$ in TIL medium for $20 \mathrm{~min}$ at $37^{\circ} \mathrm{C}$, plated in the upper chamber at a density of $1.0 \times 10^{5}$ in $200 \mu \mathrm{l}$ of medium in the presence or absence of NHG or $55 \mathrm{~A} 2 \mathrm{C}(20 \mu \mathrm{g} / \mathrm{ml})$. After $4 \mathrm{~h}$ incubation, cells in the upper surface of the insert were removed using swab, and then cells in the undersurface of the insert were fixed with methanol and stained with Giemsa's staining solution (Muto Pure Chemicals, Tokyo, Japan). Thus, six fields were counted through light microscopy and averaged for each condition studied.

\section{Isolation of Fibrocytes}

Murine fibrocytes were purified from peripheral blood and cultured as previously described. ${ }^{32}$ In brief, murine peripheral blood mononuclear cells (PBMCs) were isolated from heparinized C57BL/6 mouse blood by centrifugation over Lymphosepar II (IBL) according to the manufacturer's protocol. Murine PBMCs were cultured in TIL medium containing $10 \%$ fetal bovine serum and $10 \%$ mouse serum, $2 \mathrm{mM}$ glutamine, $100 \mathrm{units} / \mathrm{ml}$ penicillin, and $100 \mu \mathrm{g} / \mathrm{ml}$ streptomycin on a 24 -well plate at a density of $2 \times 10^{6}$ cells in $1 \mathrm{ml}$ of medium. After 2 days, nonadherent cells were removed by gentle aspiration, and media were replaced. After 10 days, the adherent crude fibrocyte preparations were lifted using $0.05 \%$ EDTA in PBS for use of flow cytometry and RT-
PCR analysis. For flow cytometry analysis, anti-CD3, B220, and CD14 antibodies were used. (CD3, CD14: BD Biosciences and B220: eBioscience, San Diego, CA, USA).

\section{Measurement of $\alpha 9$ Integrin and Type I Collagen Expression in Murine Fibrocytes}

The cell surface expression of $\alpha 9$ integrin on isolated fibrocytes was evaluated by flow cytometry. The expression of $\alpha 9$ integrin or type I collagen mRNA was evaluated by RTPCR. For RT-PCR, to control for any difference in quantity of total RNA among the samples, GAPDH mRNA expression was evaluated simultaneously. Total RNA was extracted from isolated fibrocyte using TRIzol (Invitrogen). First-strand cDNA was generated with the Transcriptor First-Strand cDNA Synthesis Kit (Roche). PCR amplification was performed using gene-specific primers and TaKaRa Ex Taq (Takara Bio, Shiga, Japan). The primers for type I collagen were as follows: type I collagen: $5^{\prime}$-TTTGTGGACCTCCG GCTC- $3^{\prime}$ and $5^{\prime}$-AAGCACAGCACTCGCCCT- $3^{\prime}$ (the primers for $\alpha 9$ integrin and GAPDH were described above). PCR was performed with 35 cycles of $30 \mathrm{~s}$ of denaturation at $94^{\circ} \mathrm{C}, 30 \mathrm{~s}$ of annealing at $58^{\circ} \mathrm{C}$, and $30 \mathrm{~s}$ of extension at $72^{\circ} \mathrm{C}$, followed by $5 \mathrm{~min}$ of final extension at $72^{\circ} \mathrm{C}$. PCR products were separated by electrophoresis using $1.5 \%$ agarose gels and viewed under ultraviolet light after ethidium bromide staining.

\section{Statistical Analysis}

Student's $t$-test was used for comparison of means between groups. A $P$-value of 0.05 was considered significant. The error bars indicate the s.e.m.

\section{Results}

\section{Three Distinct Phases of Wound Healing}

In this study, to assess macroscopic healing process, fullthickness skin excisional wounds were made in mice using a $5-\mathrm{mm}$ punch and the area of each open wound was traced at $0,3,5,7,10$, and 14 days after wounding. We found that the area of open wound was significantly reduced at two time points: from day 0 to day 5 and from day 7 to day 10 . However, the area of open wound remained unchanged if any from day 5 to day 7 (Figure 1). According to previous reports, re-epithelialization and contraction of granulation tissue are important processes that can reduce the area of open wound, ${ }^{1,2}$ and the approximate timings of these process are from day 1 to day 2 and from day 4 to day 14 after wounding, respectively. In addition, granulation tissue formation occurs from day 4 to day 7 after wounding between re-epithelialization phase and wound contraction phase. ${ }^{33}$ Therefore, we divided the process of full-thickness skin excisional wound healing into three phases: the early phase from day 0 to day 5 , the middle phase from day 5 to day 7 , and the late phase from day 7 to day 14 after wounding (Figure 1). These early, middle, and late phases are thought to correspond to the phases of re-epithelialization, formation of 


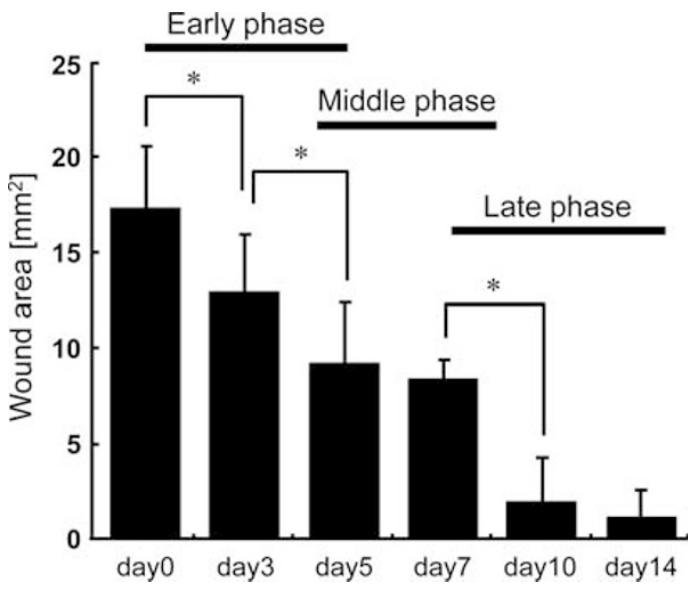

Figure 1 Kinetics of wound closure. Wound closure was measured at the indicated time points after wounding, and the edges of the wound were traced onto a transparency, and the areas of open wounds were calculated. The area of open wound was significantly reduced at two time points: during the early phase from day 0 to day 5 and middle-late phase from day 7 to 10 . For each time point at least six wounds were measured. ${ }^{\star} P<0.05$.

granulation tissue, and contraction of granulation tissue, respectively. $4,33,34$

\section{Induction of $\alpha 9$ Integrin and Its Ligands during the Process of Wound Healing}

We next examined whether the expression of $\alpha 9$ integrin and its ligands are induced after skin wounding. The gene expression of $\alpha 9$ integrin was induced on day 1 and its upregulation was maintained all the time after wounding from day 3 to day 10 (Figure $2 \mathrm{a}$ ). We tested the expression of wellknown ligands for $\alpha 9$ integrins, OPN and TN-C. Although both ligands are induced after wounding, the peak OPN gene expression was detected at 1 day after wounding (Figure 2c), whereas TN-C was at 5 days after wounding (Figure $2 \mathrm{~d}$ ), suggesting the distinct roles of these ECM proteins in the healing process. The gene expression of $\alpha 4$ integrin, which possesses a structural similarity with $\alpha 9$ integrin, ${ }^{35}$ was induced from day 1 to day 10 (Figure $2 \mathrm{~b}$ ). Thus, the kinetics of gene expression between $\alpha 4$ and $\alpha 9$ integrin was very similar. These results suggest that interactions of $\alpha 9$ or $\alpha 4$ integrins and their ligands take place in wounds and may be involved in the skin wound healing process.

\section{Formation of Granulation Tissue is Hampered by Blocking $\alpha \mathbf{9}$ Integrin}

To examine the role of $\alpha 9$ integrin in the wound healing process, the blocking antibody against $\alpha 9$ integrin (clone: $55 \mathrm{~A} 2 \mathrm{C}$ ) was given to the mice twice at 1 day before and at 2 days after making full-thickness skin excisional wound (Figure 3). It has been shown that $\alpha 9$ integrin is involved in the process of re-epithelialization, ${ }^{36}$ which occurs during the first phase of wound healing. Granulation tissue formation critically depends on the proliferation and migration of fibroblasts and angiogenesis that occur during the middle phase of wound healing. Granulation tissue is defined as the area that consist of the collection of vimentin-positive fibroblasts, CD31-positive newly formed blood vessels, and F4/ 80-positive macrophages (Figure $4 \mathrm{a}-\mathrm{c}$ ). Although granulation tissue was not detected at 3 days after wounding, most of wound site were occupied by granulation tissue at 10 days after wounding (Figure $4 \mathrm{~d}$ ). It should be noted that granulation tissue area was significantly reduced on day 7 in 55A2C-treated mice when compared with NHG-treated mice (Figure 5a and b). Consistent to these data shown in Figure 5, the density of vimentin-positive fibroblasts within granulation tissue was significantly reduced on day 7 in 55A2Ctreated mice (Figure 6a). Taken together, we found that the interaction of $\alpha 9$ integrin with its ligands has a pivotal role in the formation of granulation tissue. Angiogenesis is necessary in wound healing to sustain the newly formed granulation tissue. Macrophage infiltration into the wound site is also important for debridement and provides a source of growth factors to repair skin. ${ }^{2,33,34}$ Therefore, we examined the density of CD31-positive blood vessels and F4/80-positive macrophages within wound site at 7 days after wounding. Neither angiogenesis nor macrophage infiltration were altered in 55A2C-treated mice (Figure 6a). It should be pointed out that macrophage infiltration is evident at early phase of wound healing and macrophage may influence subsequent wound healing process. ${ }^{33}$ Therefore, we also examined the effect of antibody treatment on the macrophage infiltration on day 3. However, we found that macrophage infiltration was not impaired by antibody treatment on day 3 (Figure 6b). We then tested whether the reduction of vimentin-positive fibroblasts is due to the inhibition of fibroblast proliferation. Therefore, we analyzed Ki-67-positive cells within granulation tissue. In 55A2C-treated mice, although the density of fibroblasts within granulation tissue was significantly reduced, the ratio of Ki-67-positive cells against fibroblasts within granulation tissue was not altered on day 7 (Figure 6c). These data suggested that the interaction of $\alpha 9$ integrin with its ligands is not involved in fibroblast proliferation during the formation of granulation tissue.

\section{Wound Contraction is not Affected by Blocking $\alpha 9$ Integrin}

The critical process in the late phase of wound healing is the contraction of granulation tissue, which is reflected by connective tissue wound width. Wound width is expressed by the distance between the cut ends of the connective tissues (as indicated by closed arrows in Figure 7a). Kinetics of wound contraction was depicted as representative histology in Figure 7b. As summarized in Figure 7c, wound width is markedly reduced between day 7 and day 10, indicating that wound contraction occurs from day 7 to day 10 , which is consistent with our data that open wound area is significantly reduced at late phase (Figure 1). The contraction force is provided by the differentiated myofibroblasts within granulation tissue. ${ }^{37}$ Myofibroblasts were marked as $\alpha$-SMA-positive cells as 

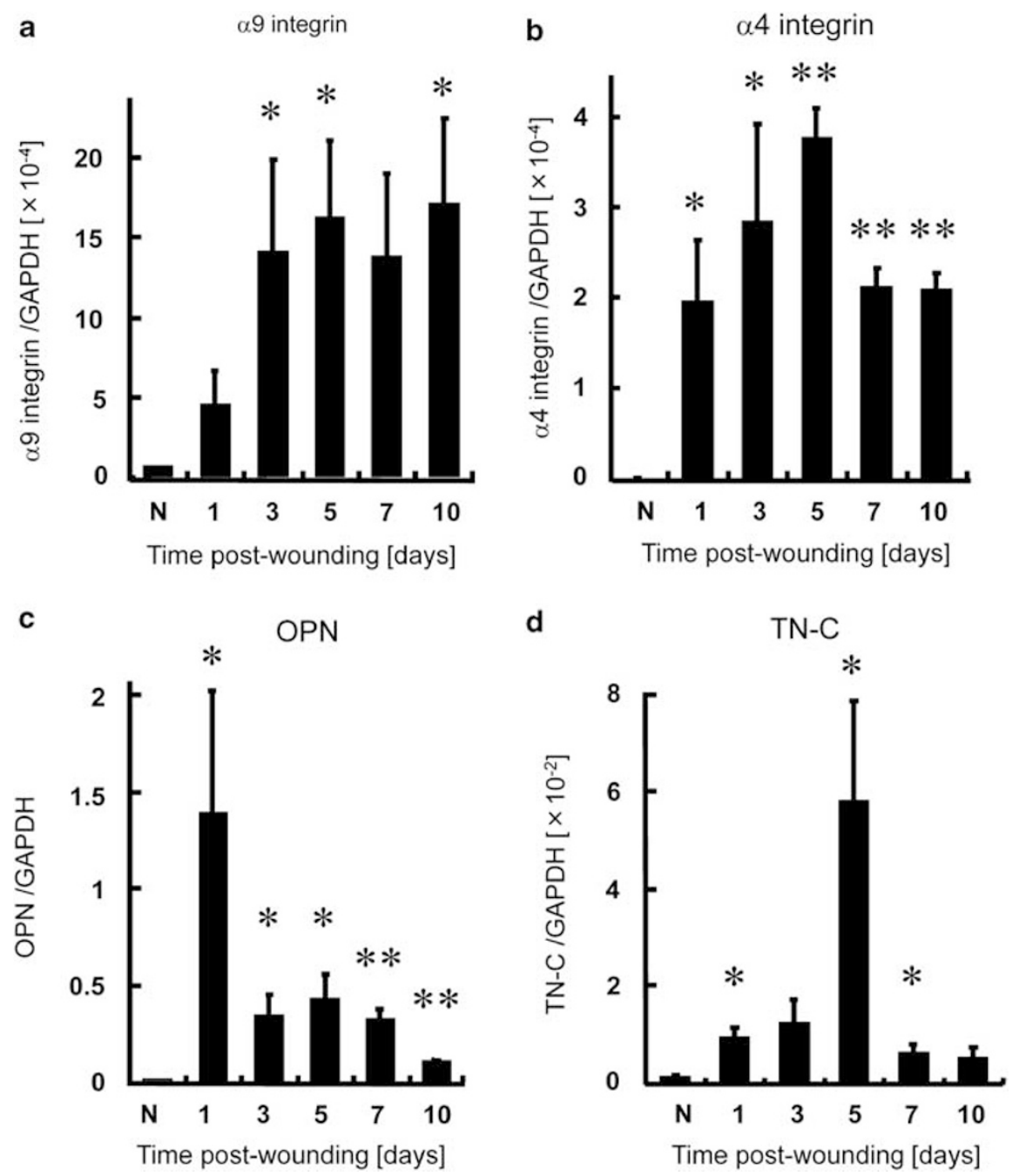

Figure 2 Induction of gene expression of $\alpha 9$ integrin and its ligands. The gene expression of $\alpha 9$ integrin (a), $\alpha 4$ integrin (b), OPN (c), and TN-C (d) in wound site at the indicated time points after wounding. For each time point at least four wounds were examined. N: normal skin. ${ }^{\star} P<0.05 ;{ }^{*} P<0.005$.

\section{C57BL/6 8weeks 우}

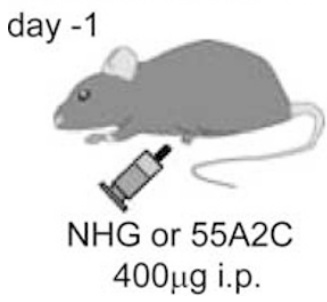

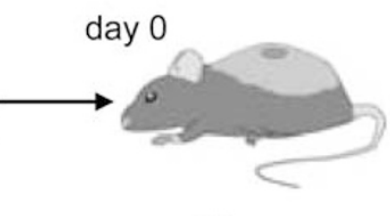

$\phi 5 \mathrm{~mm}$

biopsy

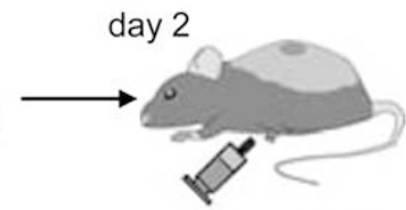

NHG or $55 \mathrm{~A} 2 \mathrm{C}$ $400 \mu$ i.p. day $3,5,7,10,14$

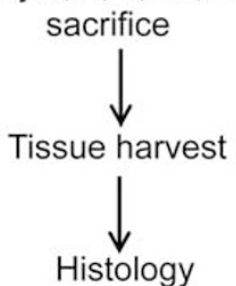

Figure 3 Treatment protocol of full-thickness skin excisional wound model. Mice were treated by administration of the blocking antibody against $\alpha 9$ integrin. NHG or 55A2C was given to the mouse at 1 day before and at 2 days after making wounds.

shown in Figure $7 \mathrm{~d}$. The $\alpha$-SMA staining was peaked on day 7 and significantly reduced at 14 days after wounding, again confirming that wound contraction occurs from day 7 to day 10 (Figure 7d). However, $\alpha$-SMA-positive area did not differ between NHG- and 55A2C-treated mice at 7 and 10 days after wounding (Figure 7d). Furthermore, western blot ana- lysis of wounded tissues showed that the expression of $\alpha$-SMA protein did not differ between NHG- and 55A2Ctreated mice at 7 and 10 days after wounding (Figure $7 \mathrm{e}$ and $\mathrm{f}$ ). Consistent with these findings, wound width was not significantly different between NHG- and 55A2C-treated mice at each time point after wounding (Figure $7 \mathrm{c}$ ). Thus, 

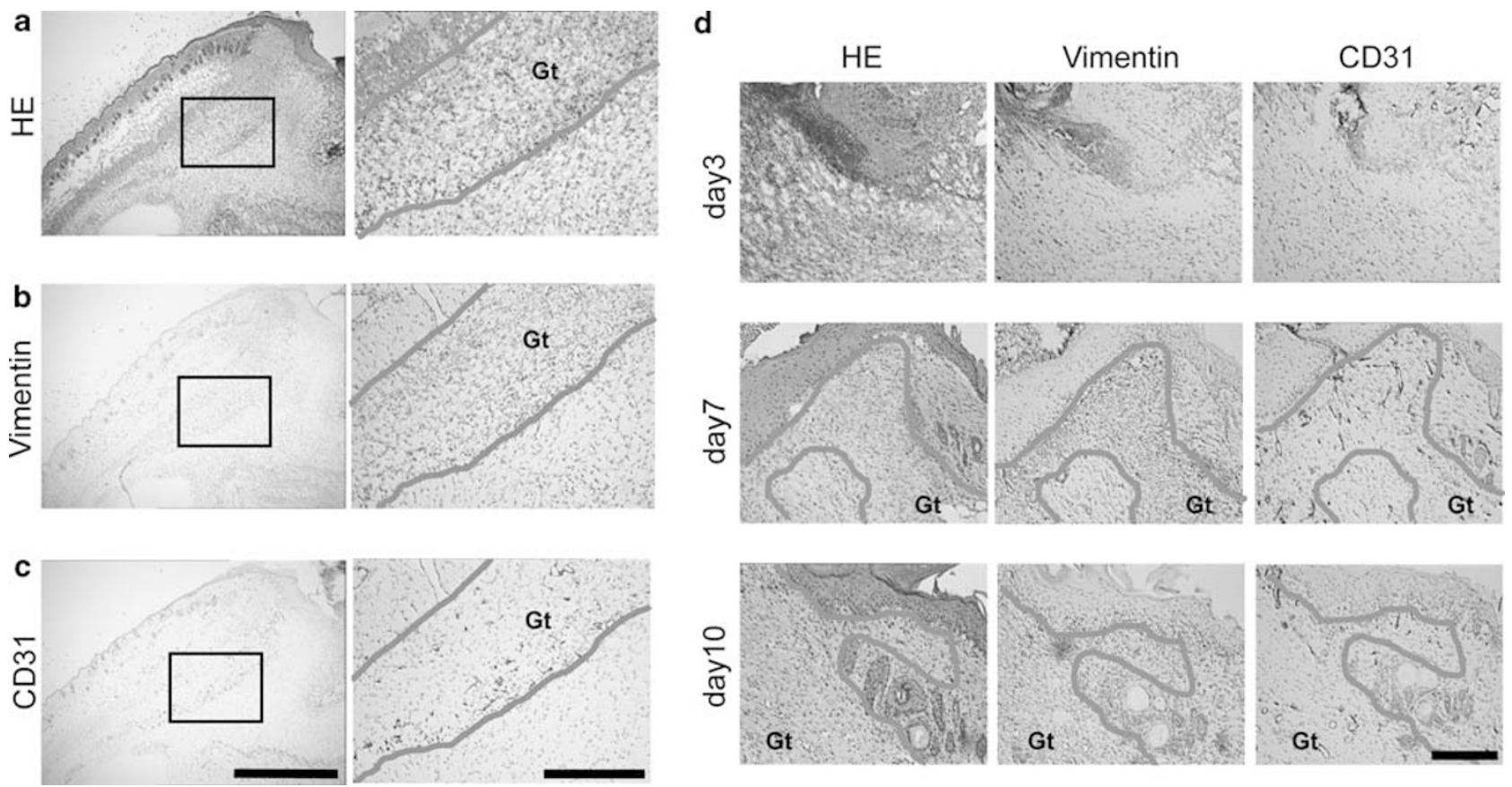

Figure 4 Evaluation of granulation tissue. Granulation tissue (Gt) was defined by dense collection of fibroblasts (a) and vimentin-positive cells (b) and formation of CD31-positive blood vessels (c). (d) Kinetics of granulation tissue formation. Tissues were obtained at indicated time points and were marked as Gt according to the definition described above. Solid lines encompass granulation tissue. Scale bars in c, $500 \mu \mathrm{m}$ (low magnification) and $200 \mu \mathrm{m}$ (high magnification); scale bar in d, $200 \mu \mathrm{m}$ (color images in this figure are mentioned in Supplementary Material 1).

our data showed that the interaction of $\alpha 9$ integrin and its ligands is not critically involved in the process of wound contraction.

\section{Adhesion and Migration of Fibroblasts are Impaired by Blocking $\alpha 9$ Integrin}

We then analyzed the molecular basis for the reduction of wound area (Figure 5a and b) and fibroblast density (Figure $6 \mathrm{a})$ in granulation tissue in $55 \mathrm{~A} 2 \mathrm{C}$-treated mice. We found that fibroblasts isolated from wound site at each time point expressed $\alpha 9$ integrin (Figure 8a). Next, dermal fibroblasts obtained from uninjured subcutaneous tissue of adult mice were cultured. These cells were $\mathrm{F} 4 / 80^{-}$cells (data not shown $^{24}$ ) and were positive for vimentin and negative for $\alpha$-SMA and showed morphological features of fibroblasts (Figure $8 \mathrm{~b}^{24}$ ). Importantly, dermal fibroblasts expressed $\alpha 9$ integrin as detected by flow cytometry and western blot analysis (Figure $8 \mathrm{c}$ and d, respectively). $\alpha 9$ Integrin expressed by these fibroblasts is functional as cells were able to bind to its ligand, TN-C, and this adhesion was specifically inhibited by $55 \mathrm{~A} 2 \mathrm{C}$ (Figure 8e). In addition, we found that TN-C induced significant migration of dermal fibroblasts and this migration was specifically inhibited by $55 \mathrm{~A} 2 \mathrm{C}$ (Figure $8 \mathrm{f}$ ). We also found that the interaction between fibroblasts and TN-C did not induce cell proliferation and the fibroblast proliferation was not altered by 55A2C (data not shown). Taken together, these data suggest that $\alpha 9$ integrin is involved in granulation tissue formation through regulating fibroblast migration and adhesion.

\section{$\alpha 9$ Integrin was not Expressed on Circulating Fibrocyte}

Recent study has shown that there is a population of circulating fibrocytes in peripheral blood and these fibrocytes are bone marrow-derived mesenchymal progenitors that are believed to contribute to wound healing. ${ }^{38,39}$ Therefore, we examined whether $\alpha 9$ integrin is expressed on murine fibrocytes that were purified from peripheral blood as previously described. ${ }^{32}$ Murine PBMCs contained $<14 \%$ of non-T cells, non-B cells, and non-monocytes (Figure 9a). PBMCs were then cultured in vitro for 12 days as described in the Materials and Methods section and crude fibrocytes population was obtained. This population contained approximately $73 \%$ of non-T cells, non-B cells, and nonmonocytes (Figure 9b). We could not detect any expression of $\alpha 9$ integrin in fibrocytes by both flow cytometric analysis (Figure 9c) and RT-PCR analysis (Figure 9d). Nevertheless, control fibroblasts expressed both $\alpha 9$ integrin and type I collagen genes. However, fibrocytes expressed only type I collagen gene as expected, but not $\alpha 9$ integrin.

\section{DISCUSSION}

Wound healing process can be divided into three distinct phases, including: (1) re-epithelialization, induced by keratinocyte migration and proliferation, and judged by epithelial gap and keratinocyte area; (2) formation of granulation tis- 


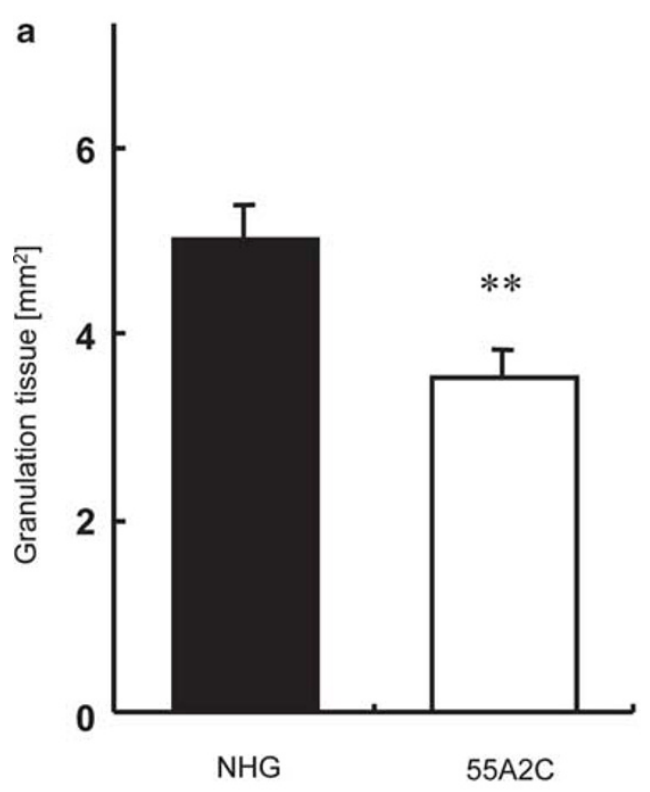

b

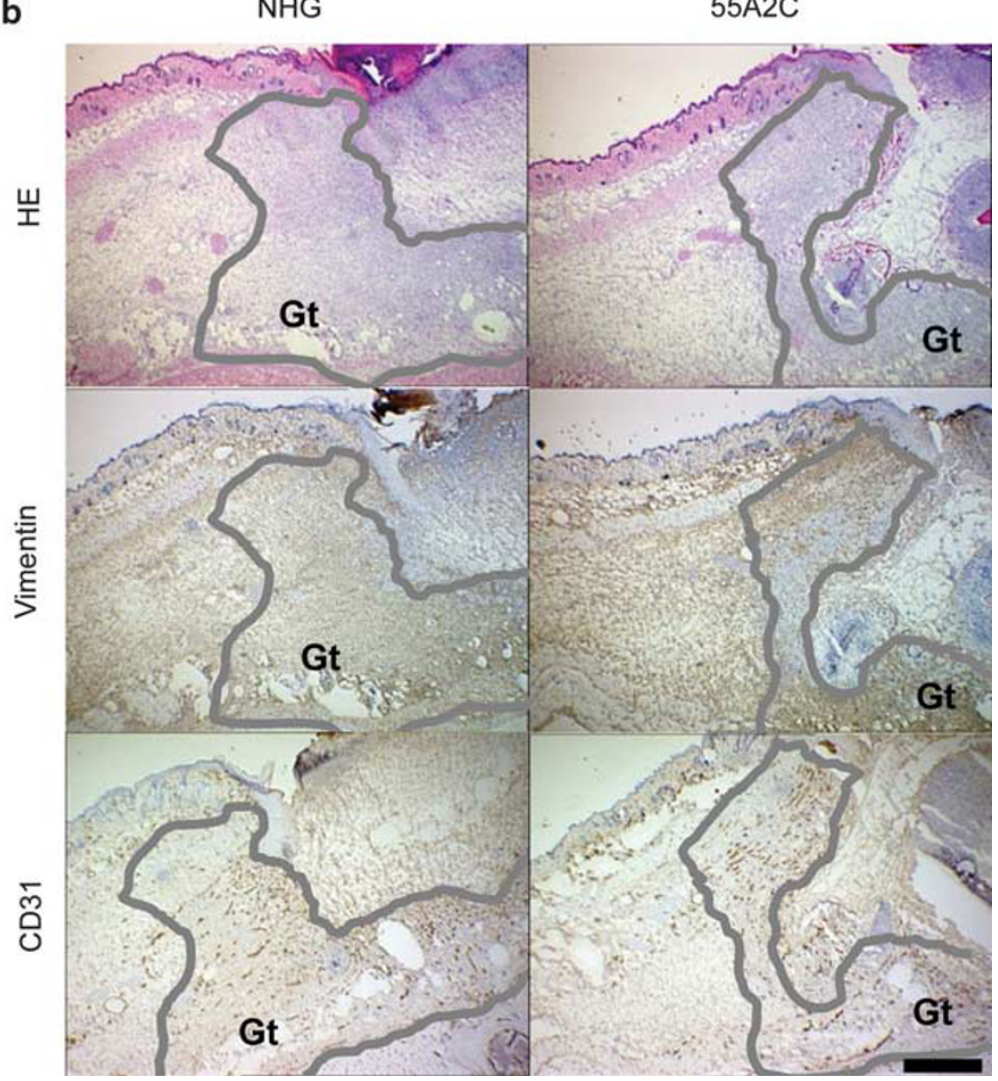

Figure 5 Formation of granulation tissue is hampered by administration of 55A2C. (a) Area of granulation tissue was measured. Granulation tissues were obtained from mice treated with NHG (closed bars) or 55A2C (open bars) on day 7. (b) Representative histology used for evaluation in (a). Solid lines encompass granulation tissue (Gt). Nine wounds were measured for each group. Scale bar in $\mathbf{b}, 500 \mu \mathrm{m}$. ${ }^{* * P}<0.005$.

sue, evidenced by dense vimentin-positive dermal fibroblasts and CD31-positive blood vessels; and (3) contraction of granulation tissue, facilitated by differentiation of dermal fibroblasts into myofibroblasts. Previous reports showed that the interaction of various integrins with ECM proteins has critical roles in distinct phases of skin wound healing process through the modulation of neutrophil infiltration, ${ }^{40}$ re-epithelialization, ${ }^{8,41}$ fibroblast migration, ${ }^{42}$ angiogenesis, ${ }^{6,7}$ and myofibroblast differentiation. ${ }^{43,44}$ Migrating keratinocytes at the wound edge express several integrins, including collagen receptor $\alpha 2 \beta 1$, laminin receptors $\alpha 3 \beta 1$ and $\alpha 6 \beta 4$, fibronectin receptors $\alpha \mathrm{v} \beta 6$ and $\alpha 5 \beta 1$, and vitronectin receptor $\alpha \mathrm{v} \beta 5$. $^{41,45}$ These integrins have a critical role in keratinocyte migration and proliferation, and thus the re-epthelialization process. $\alpha 9 \beta 1$ integrin is found to be expressed on migrating keratinocytes. ${ }^{20}$ It has been shown that the proliferation of keratinocytes was suppressed during skin wound healing under the condition in which epithelial cell lacks $\alpha 9$ integrin. The reduced keratinocyte proliferation observed in these mice negatively affect wound healing, resulting in a thinner migrating epithelium, thus showing that $\alpha 9$ integrin is crucial for efficient and proper re-epithelialization during cutaneous wound healing. ${ }^{36}$ However, the role of $\alpha 9$ integrin at various healing phases of full-thickness wounds in mice still remains to be elucidated. Therefore, we examined the role of $\alpha 9$ integrin during the course of wound healing using antimouse $\alpha 9$ integrin antibody (clone: 55A2C).

\section{$\alpha 9$ Integrin is Involved in the Formation of Granulation Tissue}

Approximately 4 days after injury, granulation tissues, which are composed of macrophages, fibroblasts, newly blood vessels, and collagens, begin to be formed in wound site. Macrophages are thought to be important for debridement of dead cells and provide a source of growth factors to cause the proliferation of endothelial cells or fibroblasts. ${ }^{2,33,34}$ Fibroblasts are the most important mesenchymal cells involved in wound healing and the main source of ECM deposition and reorganization within the wound bed. Among several ECM proteins, collagen produced by fibroblasts causes fibrinogenesis and strengthens the wounds. Angiogenesis is necessary in wound healing to sustain the newly formed granulation tissue. Thus, it has been thought that various types of cells in granulation tissue affect the quality of wound healing processes. Dermal fibroblasts strongly expressed $\alpha 9$ integrin and dermal fibroblast migration was significantly blocked by $55 \mathrm{~A} 2 \mathrm{C}$ in vitro, indicating that $\alpha 9$ integrin is involved in fibroblast movement (Figure 8). Furthermore, it 
a

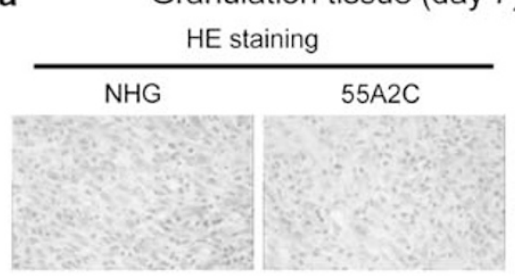

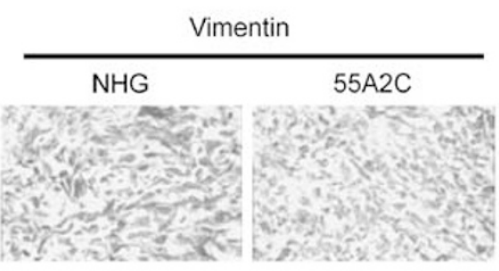
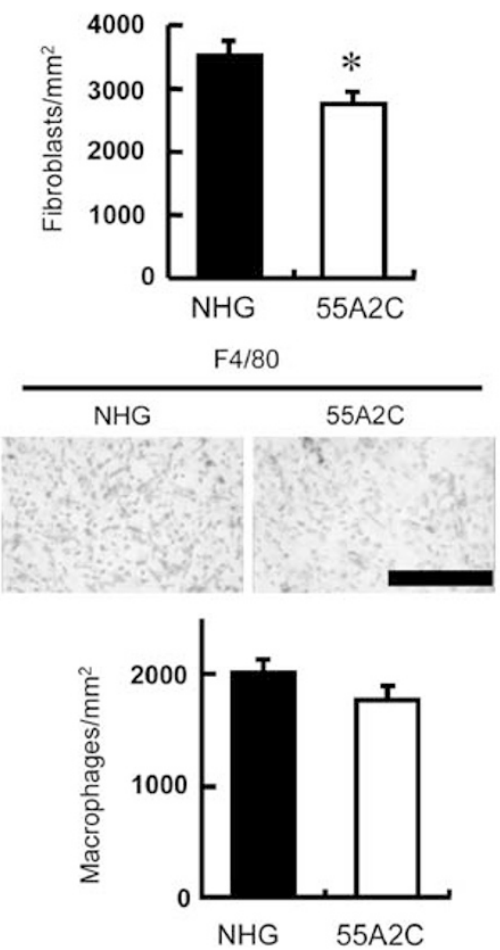

b
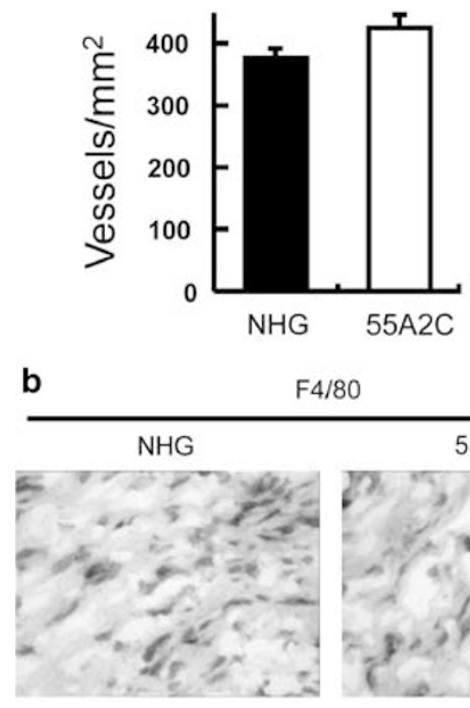

C

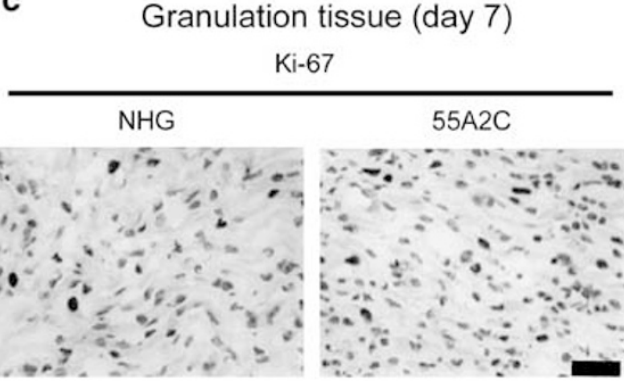

$\mathrm{F} 4 / 80$
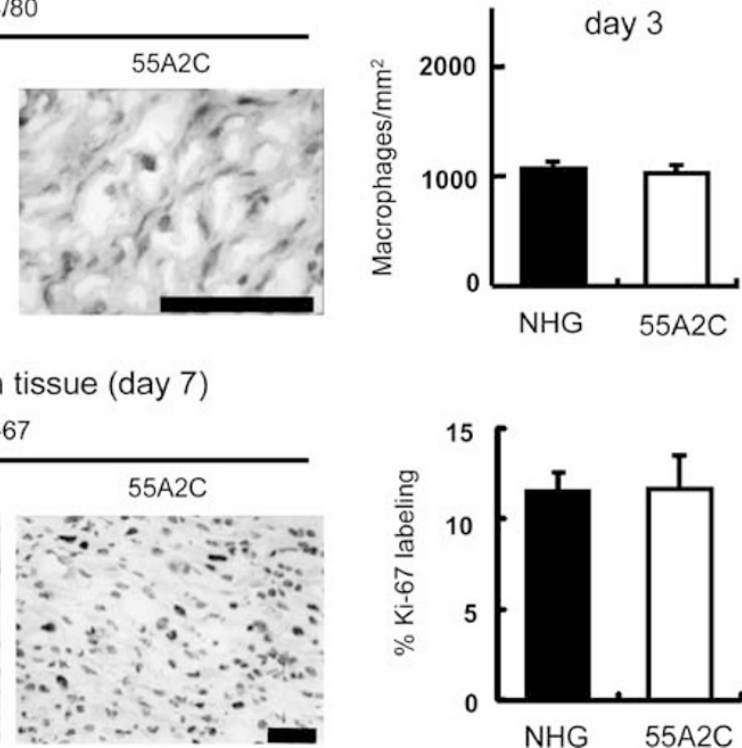

Figure 6 Dermal fibroblast density was significantly decreased in 55A2C-treated wounds. (a) Representative histology from mice treated with NHG (left panels; closed bars) or 55A2C (right panels; open bars) on day 7. Numbers of dermal fibroblasts, CD31-positive blood vessels, and F4/80-positive macrophages were counted in granulation tissue. (b) Numbers of macrophages were quantified for NHG- (closed bars) and 55A2C-treated wounds (open bars) on day 3. (c) Ratio of Ki-67-positive proliferative cells against fibroblasts within NHG- (closed bars) and 55A2C-treated (open bars) granulation tissue on day 7. Six to nine wounds were measured for each group, and 6 fields were counted through light microscopy for each section. Scale bars in a-c, $100 \mu$ m. ${ }^{\star} P<0.05$ (color images in this figure are mentioned in Supplementary Material 2). 
a

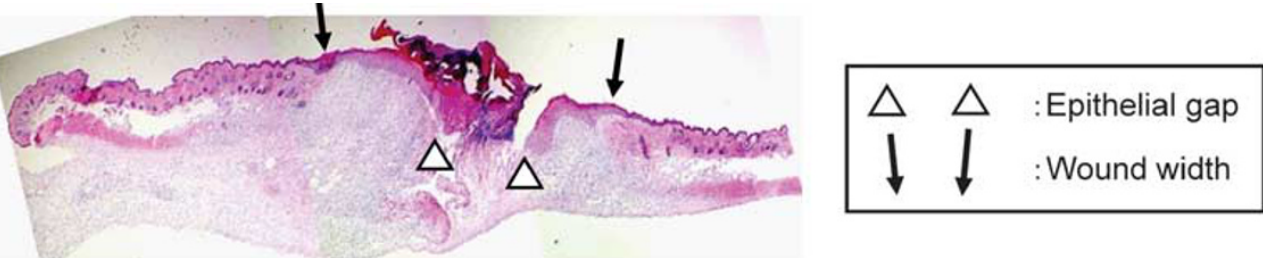

b

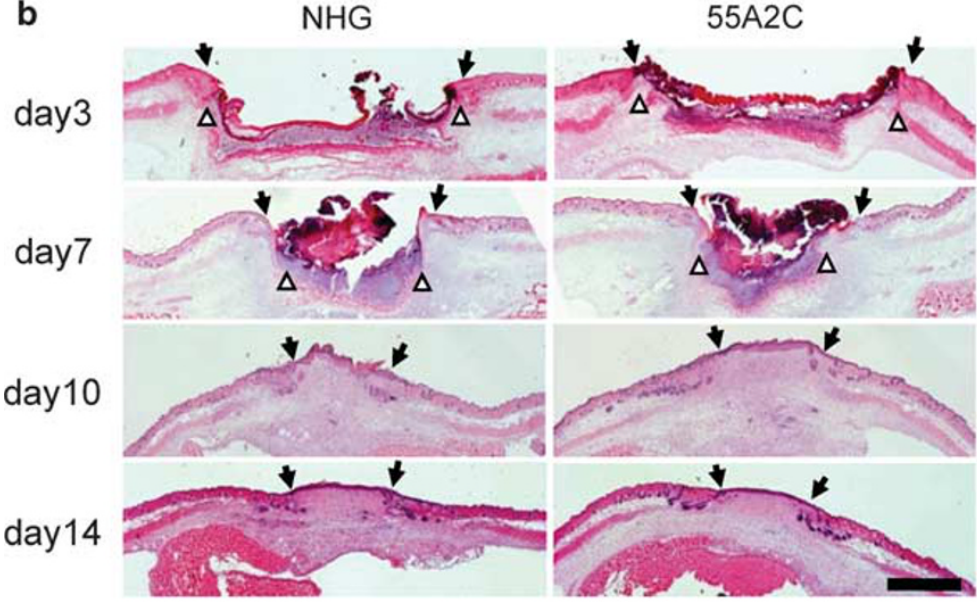

d

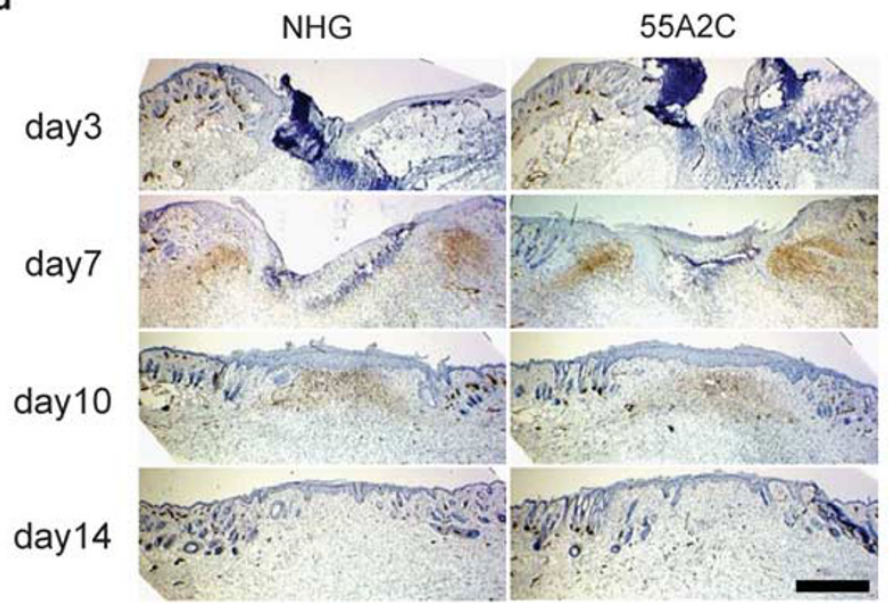

c

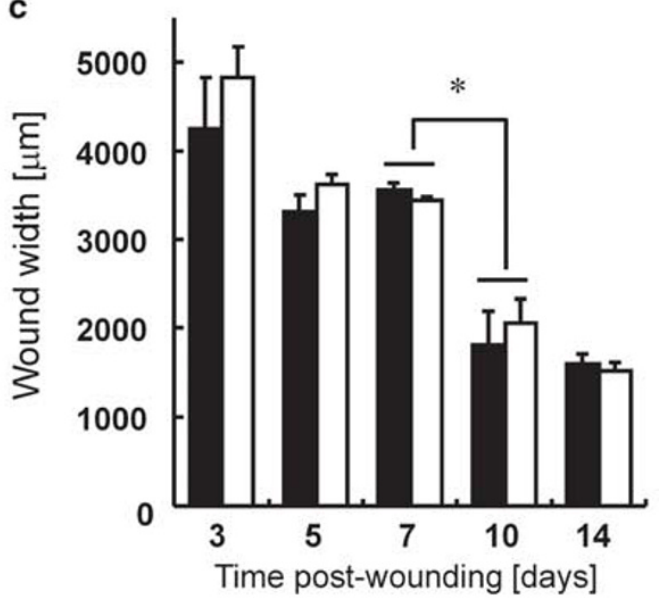

e
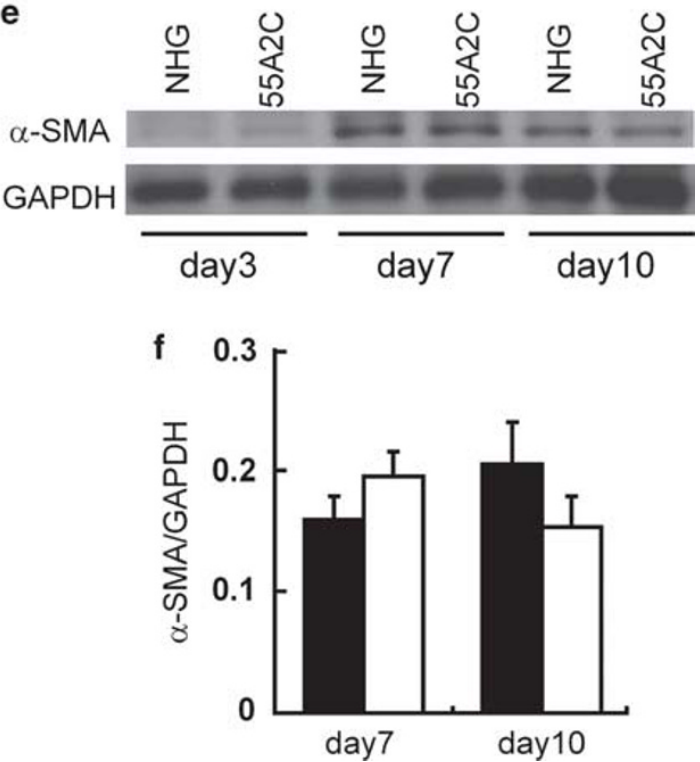

Figure 7 Histological evaluation of wounded skin tissues in 55A2C-treated mice. (a) Arrowheads represent the leading edges of migrating epithelial lips and arrows indicate the cut ends of skin connective tissue. A distance between two cut ends represents wound width. (c) Quantification of wound widths on days $3,5,7,10$, and 14. Closed bars show NHG, and open bars show 55A2C. Sections of wounded skin from mice treated with NHG (left panels) and 55A2C (right panels) were stained with hematoxylin and eosin (b) or anti- $\alpha$-SMA (d) to evaluate wound width or myofibroblast differentiation, respectively, at indicated time points. (e) Expression of $\alpha$-SMA was examined on days 3, 7, and 10 by western blotting. (f) Semiquantitative analysis of western blotting on days 7 and 10. For each time point at least six wounds (c) or five wounds (e, f) were examined for each group. Scale bar in $\mathbf{b}, 1 \mathrm{~mm} ;$ in d, $500 \mu \mathrm{m}$. ${ }^{\star P}<0.05$.

is believed that dermal fibroblasts have a critical role in the formation of granulation tissue. ${ }^{33,34}$ Therefore, we measured the granulation tissue area to evaluate whether administration of $55 \mathrm{~A} 2 \mathrm{C}$ affects the granulation tissue formation. As expected, granulation tissue area was reduced in 55A2Ctreated mice (Figure 5a and b). Moreover, the density of fibroblasts within granulation tissue was significantly reduced on day 7 in 55A2C-treated mice (Figure 6a). In wound healing process, the expression of not only $\alpha 9$ integrin but also OPN and TN-C was highly upregulated (Figure 2). In addition, it has been also reported that EDA/EIIIA segment of fibronectin, which is a ligand for $\alpha 9 \beta 1$ integrin, is ex- 


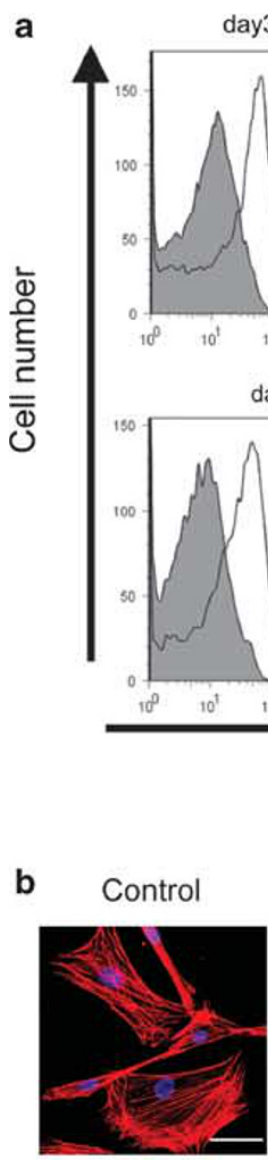

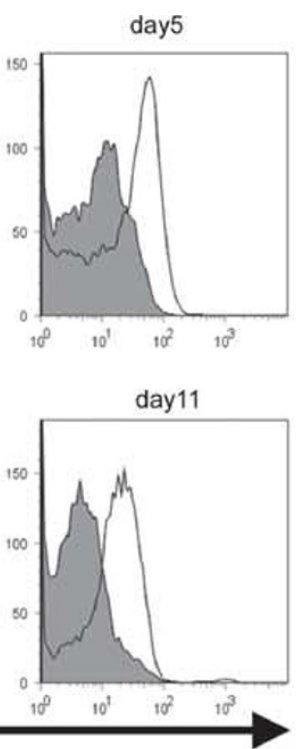

$\alpha 9$ integrin

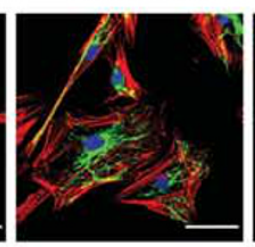

$\alpha-S M A$

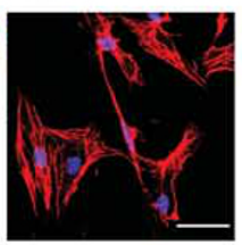

Vimentin

e

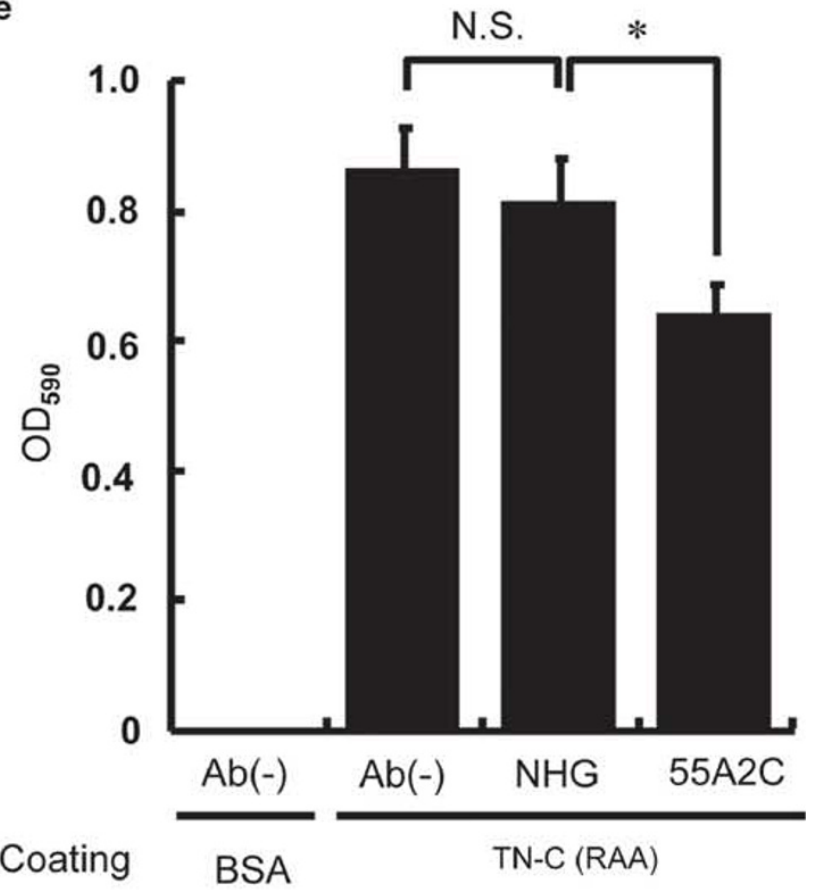

f

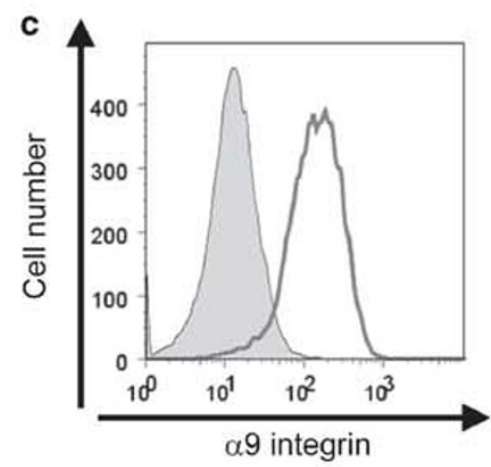

d

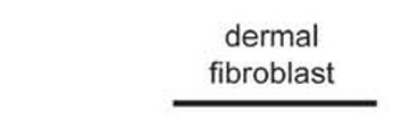

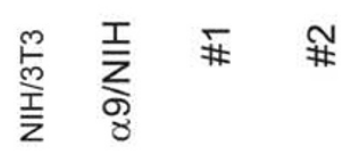

$\alpha 9$

\section{GAPDH}

Figure 8 See Figure captions on next page.

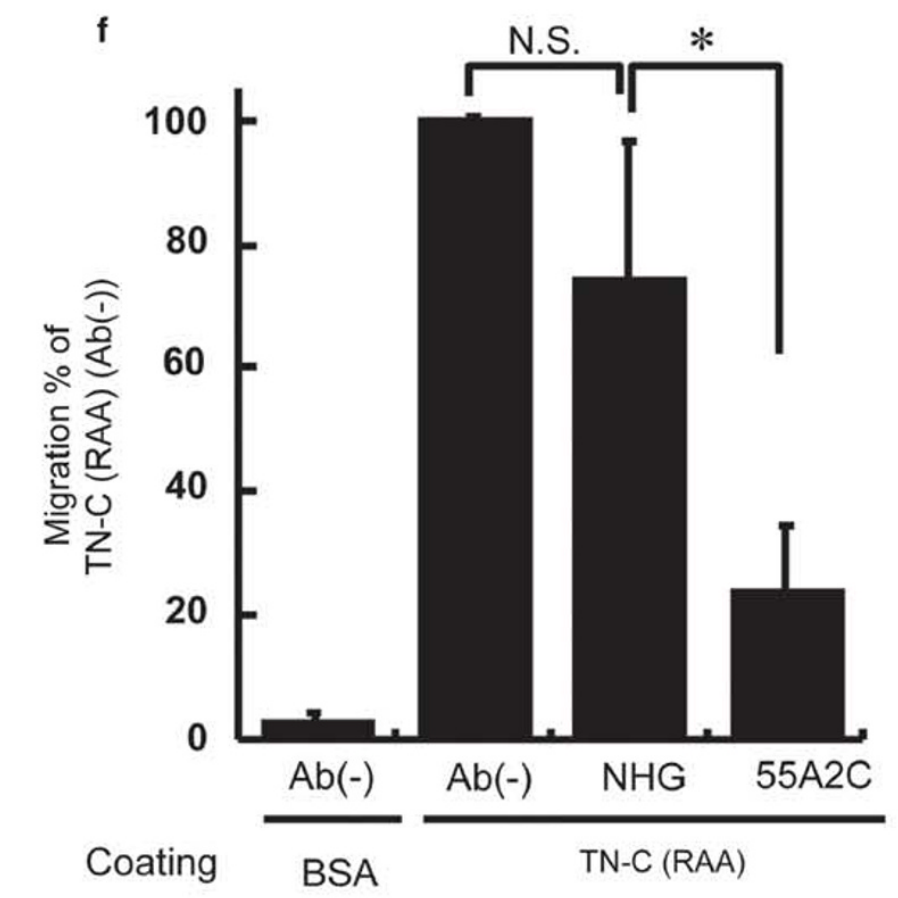


pressed during the granulation tissue phase of wound healing. ${ }^{19-22}$ It should be pointed out that $\alpha 9$ integrin is not involved in fibroblast proliferation (Figure $6 \mathrm{c}$ ). Taken together, these results and reports suggest that the interaction of $\alpha 9$ integrin on the dermal fibroblasts with its ligands, such as OPN, TN-C, and EDA/EIIIA segment of fibronectin, is involved in the migration of dermal fibroblasts into wound site, thereby facilitating the formation of granulation tissue.

It should be pointed out that the origin of $\alpha 9$ integrinpositive fibroblasts found in wounded skin is still controversial. It is reasonable to assume that fibroblasts migrate into the wounded site from surrounding skin tissues. It is possible that both migrated dermal fibroblasts from the surrounding skin tissues and residual resident dermal fibroblasts contribute to the $\alpha 9$ integrin-positive fibroblasts found in wounded skin. In addition, recent study has shown that there is a population of circulating fibrocytes in peripheral blood and these fibrocytes are bone marrow-derived mesenchymal progenitors that are believed to contribute to wound healing. ${ }^{38,39}$ Therefore, we examined whether $\alpha 9$ integrin is expressed on murine fibrocytes that were purified from peripheral blood. We could not detect any expression of $\alpha 9$ integrin on fibrocytes, suggesting that the contribution of circulating fibrocytes to the wound healing process is $\alpha 9$ integrin independent (Figure 9). It is also possible that fibrocytes initiate $\alpha 9$ expression as-or subsequent to-their entry into the wound bed.
Other important issue that should be discussed here is the contribution of $\alpha 9$ integrin to the angiogenesis. It is known that granulation tissue consists of not only dense collection of vimentin-positive fibroblasts but also CD31-positive blood vessels. Mice lacking $\alpha 9$ integrin die because of the deficient development of major lymph vessels, thoracic duct, ${ }^{23}$ raising the possibility that $\alpha 9$ integrin is also involved in angiogenesis. However, we found that the density of CD31-positive blood vessels within granulation tissues was not altered in 55A2C-treated mice (Figure 6a). In this regard, it should be noted that fibronectin and vitronectin receptors, such as $\alpha \mathrm{v} \beta 3$ and $\alpha 5 \beta 1$ integrins, were involved in the angiogenesis in skin wound healing models. ${ }^{6,7,46,47}$

\section{$\alpha 9$ Integrin is not Involved in Wound Contraction}

The contraction of granulation tissue, which is the late phase of wound healing, is mainly mediated by the differentiated myofibroblasts. ${ }^{48}$ Wound contraction and the area of $\alpha$-SMApositive cells in wounded tissue is not affected by blocking $\alpha 9$ integrin, suggesting that $\alpha 9$ integrin is not involved in myofibroblast differentiation (Figure $7 \mathrm{~d}$ ). We also found that TGF- $\beta$-induced gel contraction is not affected by $55 \mathrm{~A} 2 \mathrm{C}$, supporting the idea that the differentiation of myofibroblast is independent of the interaction between $\alpha 9$ integrin and ECM proteins (data not shown).

Although the formation of granulation tissue is impaired, the contraction of granulation tissue as well as the area of a

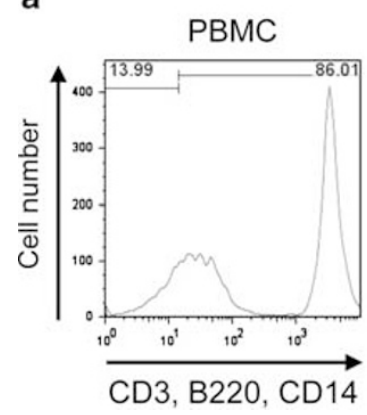

b

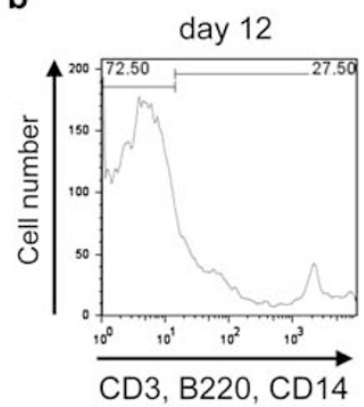

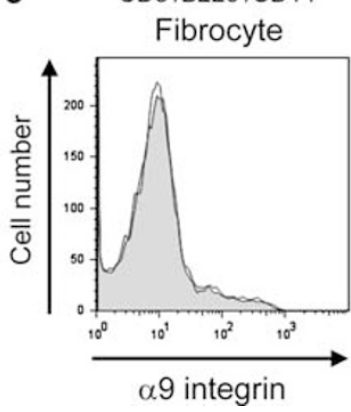

d

Fibroblast Fibrocyte
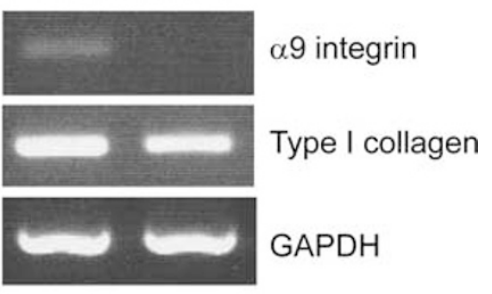

Figure 9 Expression of $\alpha 9$ integrin on fibrocytes. Murine peripheral blood mononuclear cells (PBMCs) (a) and in vitro cultured fibrocyte-enriched population (b) were stained with anti-CD3 (T cells), anti-B220 (B cells), and anti-CD14 (monocytes) antibodies. Note that non-T cells, non-B cells, and non-monocytes within PBMCs (a) and fibrocyte-enriched population (b) were 14 and $73 \%$, respectively. (c) CD3 ${ }^{-} /$B22 $^{-} / \mathrm{CD}^{-} 4^{-}$cells in (b) were stained with anti- $\alpha 9$ integrin antibody. Note that fibrocyte-enriched population was negative for $\alpha 9$ integrin expression. (d) Gene expression of fibrocyte marker, type I collagen, and $\alpha 9$ integrin in dermal fibroblasts and fibrocytes derived from PBMCs. The RT-PCR for GAPDH was used as a control.

Figure $8 \alpha 9$ Integrin mediated cell adhesion and migration of dermal fibroblasts. (a) Flow cytometry analysis of $\alpha 9$ integrin expression by fibroblasts derived from wound site. (b) Dermal fibroblasts obtained from subcutaneous tissue were stained for control Ab (left), anti-vimentin (middle), and anti- $\alpha \mathrm{SMA}$ (right) (Green). Nuclei and cytoskeletal actin were visualized by DAPI (Blue) and phalloidin (Red) staining, respectively. (c) Dermal fibroblasts used in (b) were tested for the cell surface expression of $\alpha 9$ integrin by flow cytometry. (d) $\alpha 9$ Integrin expression was also tested by western blot analysis. Two lots of cultured dermal fibroblasts 1 and 2) were used. NIH3T3 fibroblasts served for negative control, and NIH3T3 cells transfected with murine $\alpha 9$ integrin $(\alpha 9 / \mathrm{NIH})$ served for positive control. (e) Adhesion of dermal fibroblasts to ligands for $\alpha 9$ integrin. The adhesion of fibroblasts to the plates coated with $2.5 \mu \mathrm{g} / \mathrm{ml} \mathrm{TN}-\mathrm{C}(\mathrm{RAA})$ or $2.5 \mu \mathrm{g} / \mathrm{ml} \mathrm{BSA}$ was tested in the presence of $10 \mu \mathrm{g} / \mathrm{ml} \mathrm{NHG}$ or 55A2C. (f) Dermal fibroblasts migration was assessed in a Millicell Culture Plate Insert $(8.0 \mu \mathrm{m})$. Cells were added to the upper chamber of the membrane coated with $10 \mu \mathrm{g} / \mathrm{ml} \mathrm{BSA}$ or TN-C(RAA). The migration of fibroblasts to TN-C(RAA) was tested in the presence of $20 \mu \mathrm{g} / \mathrm{ml} \mathrm{NHG}$ or 55A2C. Six fields were counted through light microscopy and averaged for each group. Each value represents the mean \pm s.e.m. of three experiments. Scale bar in $\mathbf{b}, 50 \mu \mathrm{m}$. ${ }^{*} P<0.05$. 
open wound is unchanged by blocking $\alpha 9$ integrin. It is possible that the number of fibroblasts in granulation tissue of 55A2C-treated mice is sufficient for making wound contraction as the preventive effect of $55 \mathrm{~A} 2 \mathrm{C}$ on the formation of granulation tissues is partial (Figure 5a). Furthermore, other integrins such as $\alpha \mathrm{v}$ and $\alpha 5 \beta 1$, which are mainly involved in the fibroblast migration or myofibroblast differentiation, may compensate for the function of $\alpha 9$ integrin.

In summary, we found that: (1) mRNA of $\alpha 9$ integrin was upregulated in wounded skin; (2) dermal fibroblasts expressed $\alpha 9$ integrin and dermal fibroblast migration was blocked by blocking the interaction of $\alpha 9$ integrin with its ligands; and (3) in full-thickness excisional wound model, contraction of granulation tissue was not affected by blocking the interaction of $\alpha 9$ integrin with its ligands; (4) whereas formation of granulation tissue was hampered by blocking the interaction of $\alpha 9$ integrin with its ligands. These results provide the evidence that $\alpha 9$ integrin has an important role in the formation of granulation tissue through regulating fibroblast migration during skin wound healing.

Supplementary Information accompanies the paper on the Laboratory Investigation website (http://www.laboratoryinvestigation.org)

\section{DISCLOSURE/CONFLICT OF INTEREST}

The authors declare no conflict of interest.

1. Martin P. Wound healing-aiming for perfect skin regeneration. Science 1997;276:75-81.

2. Singer AJ, Clark RA. Cutaneous wound healing. N Engl J Med 1999;341:738-746.

3. Raghow R. The role of extracellular matrix in postinflammatory wound healing and fibrosis. FASEB J 1994;8:823-831.

4. Midwood KS, Williams LV, Schwarzbauer JE. Tissue repair and the dynamics of the extracellular matrix. Int J Biochem Cell Biol 2004;36:1031-1037.

5. Werner S, Grose R. Regulation of wound healing by growth factors and cytokines. Physiol Rev 2003;83:835-870.

6. Mahabeleshwar GH, Feng W, Phillips DR, et al. Integrin signaling is critical for pathological angiogenesis. J Exp Med 2006;203:2495-2507.

7. Jang YC, Arumugam S, Gibran NS, et al. Role of alpha(v) integrins and angiogenesis during wound repair. Wound Repair Regen 1999;7:375-380.

8. Santoro MM, Gaudino G. Cellular and molecular facets of keratinocyte reepithelization during wound healing. Exp Cell Res 2005;304:274-286.

9. O'Toole EA. Extracellular matrix and keratinocyte migration. Clin Exp Dermatol 2001;26:525-530.

10. Bornstein P, Sage EH. Matricellular proteins: extracellular modulators of cell function. Curr Opin Cell Biol 2002;14:608-616.

11. Kyriakides TR, Bornstein P. Matricellular proteins as modulators of wound healing and the foreign body response. Thromb Haemost 2003;90:986-992.

12. Kyriakides TR, Tam JW, Bornstein P. Accelerated wound healing in mice with a disruption of the thrombospondin 2 gene. J Invest Dermatol 1999;113:782-787.

13. Forsberg $E$, Hirsch E, Frohlich $L$, et al. Skin wounds and severed nerves heal normally in mice lacking tenascin-C. Proc Natl Acad Sci USA 1996;93:6594-6599.

14. Liaw $L$, Birk DE, Ballas $C B$, et al. Altered wound healing in mice lacking a functional osteopontin gene (spp1). J Clin Invest 1998;101:1468-1478.

15. Puolakkainen PA, Bradshaw AD, Brekken RA, et al. SPARCthrombospondin-2-double-null mice exhibit enhanced cutaneous wound healing and increased fibrovascular invasion of subcutaneous polyvinyl alcohol sponges. J Histochem Cytochem 2005;53:571-581.
16. Agah A, Kyriakides TR, Lawler J, et al. The lack of thrombospondin-1 (TSP1) dictates the course of wound healing in double-TSP1/TSP2-null mice. Am J Pathol 2002;161:831-839.

17. Yokosaki Y, Palmer EL, Prieto AL, et al. The integrin alpha 9 beta 1 mediates cell attachment to a non-RGD site in the third fibronectin type III repeat of tenascin. J Biol Chem 1994;269: 26691-26696.

18. Yokosaki $Y$, Matsuura N, Sasaki T, et al. The integrin alpha(9)beta(1) binds to a novel recognition sequence (SVVYGLR) in the thrombincleaved amino-terminal fragment of osteopontin. J Biol Chem 1999;274:36328-36334.

19. Muro AF, Chauhan AK, Gajovic S, et al. Regulated splicing of the fibronectin EDA exon is essential for proper skin wound healing and normal lifespan. J Cell Biol 2003;162:149-160.

20. Singh $\mathrm{P}$, Reimer $\mathrm{CL}$, Peters $\mathrm{JH}$, et al. The spatial and temporal expression patterns of integrin alpha9beta 1 and one of its ligands, the ElllA segment of fibronectin, in cutaneous wound healing. J Invest Dermatol 2004;123:1176-1181.

21. Liao YF, Gotwals PJ, Koteliansky VE, et al. The ElllA segment of fibronectin is a ligand for integrins alpha 9beta 1 and alpha 4beta 1 providing a novel mechanism for regulating cell adhesion by alternative splicing. J Biol Chem 2002;277:14467-14474.

22. Shinde $A V$, Bystroff $C$, Wang $C$, et al. Identification of the peptide sequences within the EIIIA (EDA) segment of fibronectin that mediate integrin alpha9beta1-dependent cellular activities. J Biol Chem 2008;283:2858-2870.

23. Huang $\mathrm{XZ}, \mathrm{Wu} \mathrm{JF}$, Ferrando $\mathrm{R}$, et al. Fatal bilateral chylothorax in mice lacking the integrin alpha9beta1. Mol Cell Biol 2000;20: 5208-5215.

24. Kanayama M, Kurotaki D, Morimoto J, et al. Alpha9 integrin and its ligands constitute critical joint microenvironments for development of autoimmune arthritis. J Immunol 2009;182:8015-8025.

25. Yahata $Y$, Shirakata $Y$, Tokumaru $S$, et al. A novel function of angiotensin II in skin wound healing. Induction of fibroblast and keratinocyte migration by angiotensin II via heparin-binding epidermal growth factor (EGF)-like growth factor-mediated EGF receptor transactivation. J Biol Chem 2006;281:13209-13216.

26. Mori R, Shaw TJ, Martin P. Molecular mechanisms linking wound inflammation and fibrosis: knockdown of osteopontin leads to rapid repair and reduced scarring. J Exp Med 2008;205:43-51.

27. Yukami T, Hasegawa $M$, Matsushita $Y$, et al. Endothelial selectins regulate skin wound healing in cooperation with L-selectin and ICAM-1. J Leukoc Biol 2007;82:519-531.

28. Bourdon MA, Ruoslahti E. Tenascin mediates cell attachment through an RGD-dependent receptor. J Cell Biol 1989;108:1149-1155.

29. Marcinkiewicz C, Taooka Y, Yokosaki Y, et al. Inhibitory effects of MLDG-containing heterodimeric disintegrins reveal distinct structural requirements for interaction of the integrin alpha 9beta 1 with VCAM-1, tenascin-C, and osteopontin. J Biol Chem 2000;275:31930-31937.

30. Taooka Y, Chen J, Yednock T, et al. The integrin alpha9beta1 mediates adhesion to activated endothelial cells and transendothelial neutrophil migration through interaction with vascular cell adhesion molecule-1. J Cell Biol 1999;145:413-420.

31. Wu RX, Laser $\mathrm{M}, \mathrm{Han} \mathrm{H}$, et al. Fibroblast migration after myocardial infarction is regulated by transient SPARC expression. J Mol Med 2006;84:241-252.

32. Abe R, Donnelly SC, Peng T, et al. Peripheral blood fibrocytes: differentiation pathway and migration to wound sites. J Immunol 2001;166:7556-7562.

33. Baum CL, Arpey CJ. Normal cutaneous wound healing: clinical correlation with cellular and molecular events. Dermatol Surg 2005;31:674-686; discussion 686.

34. Li J, Chen J, Kirsner R. Pathophysiology of acute wound healing. Clin Dermatol 2007;25:9-18.

35. Palmer EL, Ruegg C, Ferrando R, et al. Sequence and tissue distribution of the integrin alpha 9 subunit, a novel partner of beta 1 that is widely distributed in epithelia and muscle. J Cell Biol 1993;123: 1289-1297.

36. Singh $\mathrm{P}$, Chen $\mathrm{C}, \mathrm{Pal}-\mathrm{Ghosh} \mathrm{S}$, et al. Loss of integrin alpha9beta1 results in defects in proliferation, causing poor re-epithelialization during cutaneous wound healing. J Invest Dermatol 2009;129: 217-228. 
37. Grinnell F. Fibroblasts, myofibroblasts, and wound contraction. J Cell Biol 1994;124:401-404.

38. Bellini A, Mattoli S. The role of the fibrocyte, a bone marrow-derived mesenchymal progenitor, in reactive and reparative fibroses. Lab Invest 2007;87:858-870.

39. Ishii G, Sangai T, Sugiyama K, et al. In vivo characterization of bone marrow-derived fibroblasts recruited into fibrotic lesions. Stem Cells 2005;23:699-706.

40. Peters T, Sindrilaru A, Hinz B, et al. Wound-healing defect of CD18(-/-) mice due to a decrease in TGF-beta1 and myofibroblast differentiation. EMBO J 2005;24:3400-3410.

41. Watt FM. Role of integrins in regulating epidermal adhesion, growth and differentiation. EMBO J 2002;21:3919-3926.

42. Greiling D, Clark RA. Fibronectin provides a conduit for fibroblast transmigration from collagenous stroma into fibrin clot provisional matrix. J Cell Sci 1997;110(Part 7):861-870.
43. Lygoe KA, Norman JT, Marshall JF, et al. AlphaV integrins play an important role in myofibroblast differentiation. Wound Repair Regen 2004;12:461-470.

44. Lygoe KA, Wall I, Stephens $P$, et al. Role of vitronectin and fibronectin receptors in oral mucosal and dermal myofibroblast differentiation. Biol Cell 2007;99:601-614.

45. Larjava $\mathrm{H}$, Salo $\mathrm{T}$, Haapasalmi $\mathrm{K}$, et al. Expression of integrins and basement membrane components by wound keratinocytes. J Clin Invest 1993;92:1425-1435.

46. Yang JT, Rayburn $\mathrm{H}$, Hynes RO. Embryonic mesodermal defects in alpha 5 integrin-deficient mice. Development 1993;119:1093-1105.

47. Kim S, Bell K, Mousa SA, et al. Regulation of angiogenesis in vivo by ligation of integrin alpha5beta 1 with the central cell-binding domain of fibronectin. Am J Pathol 2000;156:1345-1362.

48. Gabbiani $\mathrm{G}$. The myofibroblast in wound healing and fibrocontractive diseases. J Pathol 2003;200:500-503. 